\title{
Manajemen Usaha Pengolahan Abon Ikan Lele (Clarias gariepinus) di P2MKP Jaya Mandiri Kecamatan Bulu, Kabupaten Temanggung
}

\author{
[Business management of catfish (Clarias gariepinus.) floss processing \\ in Bulu District Temanggung]
}

\author{
Indri Tri Setiawati ${ }^{1}$, Sri Ningsih ${ }^{2}$ \\ 1)Jurusan Penyuluhan Perikanan, Sekolah tinggi Perikanan \\ Jl. Cikaret No.2 Bogor, Kode Pos 16000, Jawa Barat \\ 2) Pusat Pelatihan Mandiri Kelautan Perikanan \\ Jaya Mandiri Kecamatan Bulu Kabupaten Temanggung
}

\begin{abstract}
Abstrak
Abon merupakan makanan tradisional yang biasanya digunakan untuk lauk karena rasanya yang gurih. Abon ikan lele diolah dari daging ikan lele yang berukuran besar $(>1 \mathrm{~kg})$ sehingga abon yang diperoleh mempunyai serat seperti abon dari daging sapi. Usaha pengolahan abon ikan lele mempunyai prospek yang besar karena daging ikan lele yang mudah didapat dan orang mulai bergeser mengkonsumsi ikan daripada daging merah seperti sapi. Penelitian bertujuan untuk mempelajari manajemen usaha pengolahan abon ikan lele. Penelitian dilaksanakan selama selama 21 hari dengan metode magang pada P2MKP Jaya Mandiri Kecamatan Bulu Kabupaten Temanggung. Data yang diambil adalah data primer yang diambil secara langsung yaitu observasi langsung di lapangan serta melakukan wawancara manajemen usaha pengolahan Abon Ikan Lele di P2MKP Jaya Mandiri. Hasil penelitian menunjukkan manajemen usaha pengolahan ikan lele tersebut terlaksana dengan baik dimulai dari input produksi, proses produksi, pasca produksi hingga pemasaran. Dari segi analisa usaha yang membuktikan bahwa P2MKP Jaya Mandiri adalah sebuah usaha pengolahan yang layak untuk dijalankan dan dapat menjadi sumber inovasi dan contoh dalam bidang usaha perikanan. Hasil analisa usaha ini bisa dikatakan layak dan dapat dilanjutkan karena dalam produk abon ikan lele ini mendapatkan nilai $\mathrm{R} / \mathrm{C}$ sebesar 1,29, artinya bahwa setiap pengeluaran biaya sebesar $\mathrm{Rp} 1,000$ maka akan di peroleh tambahan penerimaan sebesar Rp 1,290. Hasil perhitungan secara normal maka usaha ini layak untuk dilanjutkan.
\end{abstract}

Kata kunci: abon ikan lele; analisa usaha; manajemen usaha

\section{Abstract}

Abon or floss or shredded catfish is a traditional food that is usually used for side dishes because it tastes delicious. Catfish floss is processed from catfish meat that is large (> $1 \mathrm{~kg})$ so that the abon obtained has fiber such as abon from beef. The business of processing catfish floss has a great prospect because catfish meat is easily available and people begin to shift to consuming fish rather than red meat like beef. The study aims to study the business management of catfish floss processing. The study was conducted for 21 days with an apprenticeship method in P2MKP Jaya Mandiri, Bulu District, Temanggung Regency. The data taken is primary data taken directly, namely direct observation in the field and conducting interviews with management of catfish floss processing business in P2MKP Jaya Mandiri. The results showed that the management of catfish floss processing business was carried out well starting from production inputs, production processes, post-production to marketing. In terms of business analysis that proves that P2MKP Jaya Mandiri is a processing business that is feasible to run and can be a source of innovation and examples in the field of fisheries. The results of this business analysis can be said to be feasible and can be continued because in the catfish floss product get an R / C value of 1.29, meaning that for every expenditure of Rp 1,000, additional revenues of Rp 1.290 will be obtained. As a result of normal calculations, this business is feasible to continue. 


\section{PENDAHULUAN}

Ikan lele (Clarias gariepinus) merupakan komoditas budidaya perikanan air tawar unggulan di Jawa Tengah (Direktorat Produksi dan Usaha Budidaya 2016). Kabupaten Temanggung mengembangkan budidaya ikan air tawar seperti nila, ikan mas dan lele (Suyitno, 2014).

Ikan lele merupakan bahan pangan sumber protein hewani yaitu sekitar $22,0 \%$ hingga $46,6 \%$ (b/k). Komposisi gizi lain adalah kadar lemak $\pm 20.8(\mathrm{~b} / \mathrm{k})$, mineral $\pm 14.6 \%(\mathrm{~b} / \mathrm{k})$, air dan $\pm 6.81 \%$ (b/k) (Adebayo dkk. 2016). Ikan lele kaya akan asam amino esensial seperti essential amino (dalam \% protein): arginine $4,3 \%$, histidine $1,5 \%$, isoleucine $2,6 \%$, leucine $3,5 \%$, lysine $5,1 \%$, methionine $2,3 \%$, phenylalanine $5,0 \%$, threonine $2,0 \%$, tryptophan $0,5 \%$ dan valine 3.0\% (Robinson dan Li 2015).

Berbagai olahan diproduksi oleh masyarakat untuk menaikan tingkat penerimaan konsumen terhadap produk berbahan baku ikan lele yang bervariasi seperti nuget ikan lele (Ubadillah dan Hersoelistyori 2010), pempek ikan lele (Ririsanti dkk. 2017) dan abon ikan lele (Kusumayanti dkk. 2011).
Pengolah abon ikan lele di Kabupaten Temanggung adalah Kelompok Jaya Mandiri. Kelompok ini pada awal pembentukan merupakan Kelompok Pembudidaya Ikan, berlokasi di Desa Mondoretno Kecamatan Bulu. Usaha yang dilakukan adalah budidaya ikan nila, khususnya pembenihan. Usaha tersebut berkembang pesat. Kelompok berkeinginan untuk mengembangkan usaha pengolahan hasil perikanan guna menampung hasil produksi budidaya ikan nila.

Kelompok Pengolahan Hasil Perikanan Jaya Mandiri didirikan pada tanggal 17 Januari 2010. Tujuan didirikannya kelompok ini adalah meningkatkan nilai tambah produk hasil perikanan, membuka lapangan usaha baru dan meningkatkan pendapatan dari sektor perikanan. Pendirian kelompok ini disahkan oleh Kepala Desa Mondoretno Kecamatan Bulu, dan telah terdaftar resmi pada Dinas Peternakan dan Perikanan Kab. Temanggung.

Kelompok pengolah "Jaya Mandiri" ini kemudian ditetapkan sebagai Lembaga P2MKP Jaya Mandiri dibidang pengolahan pada tanggal 16 Maret 2015 oleh BPSDM Kementrian Kelautan dan 
Perikanan. Pelatihan yang pernah diikuti adalah Pelatihan Dasar Metodologi Pelatihan Bagi Pusat Pelatihan Mandiri Kelautan dan Perikanan Angkatan IV Tahun Anggaran 2015 Tanggal 29 Juni sampai dengan tanggal 4 Juli 2015 di BPPP Tegal. Kemudian Lembaga P2MKP Jaya Mandiri ini mengadakan pelatihan bagi masyarakat sekitar untuk pertama kali selama empat hari pada tanggal 10 sampai dengan 13 Oktober 2015.

\begin{tabular}{llr} 
Kelompok & \multicolumn{1}{c}{ Jaya } & Mandiri \\
menjalankan manajemen & didalam \\
mengkoordinir & kegiatan pengolahan
\end{tabular} abon lele. Manajemen adalah suatu proses yang terdiri dari tindakantindakan perencanaan, pengorganisasian, penggerakan dan pengawasan yang dilakukan untuk menentukan serta mencapai tujuan melalui pemanfaatan saran atau sumber-sumber daya. Dalam kehidupan sehari-hari, manajemen sangat diharapkan dan diperlukan agar tidak terjadi benturan antara masingmasing faktor yang menyebabkan tujuan tidak tercapai.

Manajemen usaha sangat diperlukan supaya dapat berjalan lancar dan mendapat hasil yang sesuai harapan. Pada manajemen sendiri terdapat beberapa fungsi sebagai bagian dari proses manajemen. Semua fungsifungsi manajemen terdapat dalam setiap kegiatan usaha. Dalam usaha perikanan, fungsi-fungsi tersebut memiliki wujud yang berbeda, tergantung dari faktorfaktor yang mempengaruhi dan jenis komoditas yang diusahakan (Rahardi, 2008).

Tujuan penelitian adalah untuk mempelajari manajemen usaha pengolahan abon ikan lele di P2MKP Jaya Mandiri yang terdiri dari meng-identifikasi manajemen usaha, cara pengolahan dan analisa usaha abon lele.

\section{BAHAN DAN METODE}

Bahan baku utama yang digunakan pada penelitian ini ikan lele. Bumbubumbu yang digunakan antara lain bawang putih, ketumbar, lengkuas yang telah diparut gula pasir dan garam dapur. Metode penelitian dilakukan dengan cara magang, yaitu penulis mengikuti setiap kegiatan sesuai dengan jadwal kegiatan. Materi penelitian ini berupa kegiatan proses pembuatan abon lele yang berkaitan dengan manajemen usaha dalam pengolahan abon lele. Penentuan responden yaitu Kelompok P2MKP ditentukan secara purposive (sengaja).

Penentuan analisa usaha menggunakan komponen-komponen sebagai berikut: (1) Biaya Investasi adalah alokasi dana kedalam usaha yang bersangkutan yang digunakan untuk pengadaan sarana dan prasaran produksi; (2) Biaya Produksi merupakan modal yang harus dikeluarkan untuk 
melakukan suatu usaha. Biaya produksi dibagi menjadi dua bagian, yaitu: (a) Biaya variabel adalah biaya yang habis dalam satu kali produksi; (b) Biaya tetap adalah biaya yang penggunaannya habis dalam satu masa produksi. Selain investasi dan biaya produksi, terdapat kelayakan investasi, yaitu:

- Break event point adalah perbandingan antara nilai hasil penjualan produksi dengan biaya produksi. Nilai yang diperoleh merupakan titik impas sebuah usaha dan menggabarkan kondisi usaha tidak mengalami keuntungan maupun kerugian.

$$
\begin{aligned}
\operatorname{BEP}(\mathrm{Rp}) & =\frac{\text { Biaya Tetap }}{1-\text { Biaya Variabel/Penjualan }} \\
\operatorname{BEP}(\text { Unit }) & =\frac{\text { Biaya Tetap }}{\text { Harga Jual - Biaya Variabel }}
\end{aligned}
$$

- Return Of Invesment merupakan nilai keuntungan yang diperoleh pengusaha yang diperoleh pengusaha dari setiap jumlah uang yang diinvestasikan dalam periode waktu tertentu.

$$
\text { ROI }=\frac{\text { Laba usaha }}{\text { Modal usaha }} \times 100 \%
$$

- Dengan R/C ini bisa dilihat kelayakan suatu usaha. Bila nilainya lebih dari 1 berarti usaha tersebut layak untuk dilaksanakan, digunakan rumus:

$$
\mathrm{R} / \mathrm{C}=\frac{\text { Total Penerimaan }}{\text { Total Biaya Produksi }}
$$

- Payback period dapat diartikan sebagai jangka waktu kembalinya investasi yang telah dikeluarkan, melalui keuntungan yang diperoleh.

Payback Periode $=\frac{\text { Total Investasi Awal }}{\text { Keuntungan Akhir Periode }}$

\section{HASIL DAN PEMBAHASAN}

\section{Hasil}

Identifikasi manajemen usaha

Hasil identifikasi manajemen usaha pada Kelompok P2MKP Jaya Mandiri meliputi pasokan input, proses produksi, paska produksi, dan pemasaran, dapat dilihat pada Gambar 1.

Bahan baku yang digunakan adalah ikan lele yang berukuran $1-2 \mathrm{~kg}$ yang dibeli dari mitra budidaya atau pengepul yang ada di daerah Temanggung.

Jumlah bahan baku yang dibutuhkan untuk satu kali siklus produksi adalah $10 \mathrm{~kg}$ ikan lele. Kebutuhan bahan baku bisa meningkat apabila permintaan pasar meningkat. Harga bahan baku ikan lele yaitu $1 \mathrm{~kg}$ seharga $\mathrm{Rp} 20.000,00$. Bahan baku pembuatan abon lele bisa dilihat pada Gambar 2. 


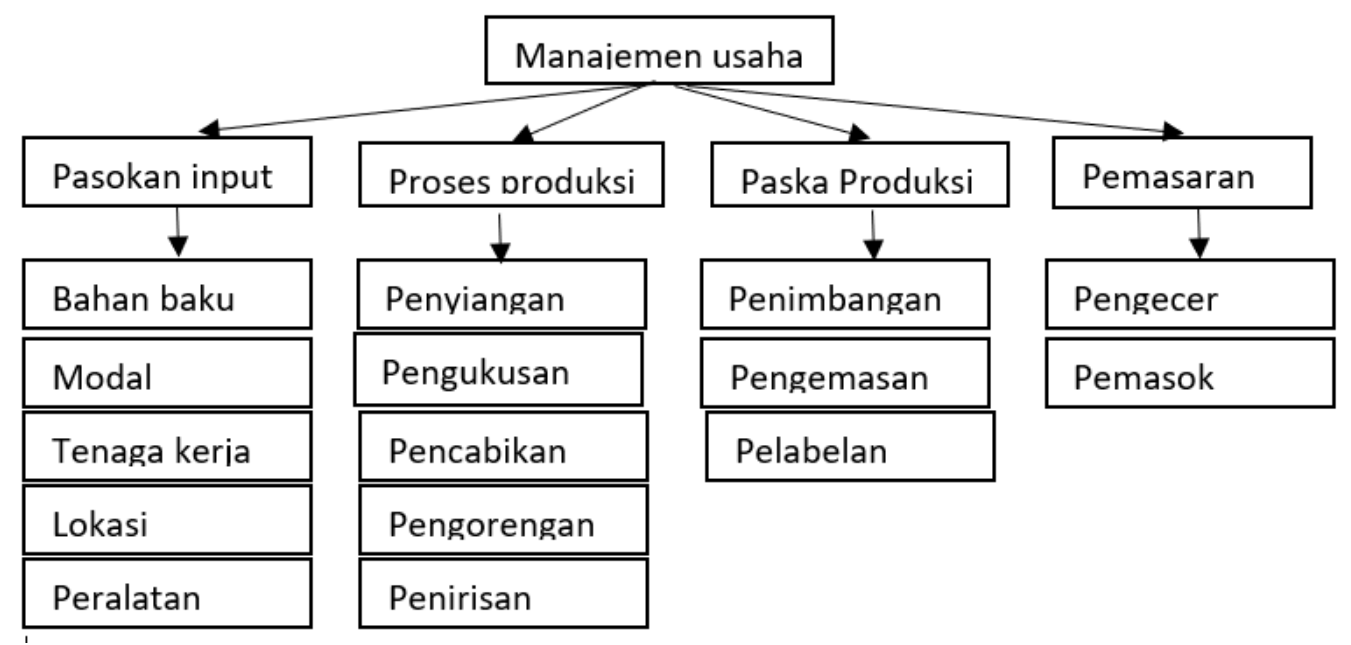

Gambar 1. Manajemen usaha perikanan

Modal yang digunakan untuk mengawali usaha berasal dari modal pribadi. Adapun bantuan berupa peralatan dan bahan baku dari Gerakan Kewirausahaan Nasional dan Disperindagkop, dialokasikan untuk meningkatkan sarana dan prasarana dalam pembuatan usaha pengolahan ikan dan dimanfaatkan sebaik mungkin agar usaha tersebut tetap dapat berjalan hingga saat ini.

Modal yang berasal dari modal pribadi adalah sebesar Rp 2.000.000,00 dan dana bantuan sebesar $R p$ 35.000.000,00. Sehingga total modal yang dimiliki oleh usaha pengolahan abon lele adalah sebesar $\mathrm{Rp}$ 37.000.000,00.

Peralatan yang digunakan dalam proses produksi adalah mesin spinner, kompor gas, wajan besar, tampah, baskom besar, mesin sealer, mesin print tanggal, pisau, cobek, talenan, serok, spatula, etalase, timbangan digital, gilingan adonan dan celemek.

Bangunan P2MKP Jaya Mandiri menyatu dengan rumah pribadi Ibu Sri Ningsih selaku ketua P2MKP Jaya Mandiri. Ruang pemasaran hasil olahan abon lele terdapat di bagian depan rumah, sedangkan bagian belakang untuk menyimpan bahan baku utama dan bagian atas atau di lantai dua adalah ruang keluarga Ibu Sri Ningsih.

\section{Proses Produksi Pengolahan Abon Lele}

Cara pengolahan abon ikan lele memerlukan bahan baku yaitu ikan lele dan rempah-rempah lainnya. Proses pembuatan meliputi: (a) penyiangan; (b) pengukusan; (d) pencabikan; penggorengan dan pemberian bumbu; (e) penirisan dan pengepresan. Berikut adalah gambar proses pengolahan abon lele. 


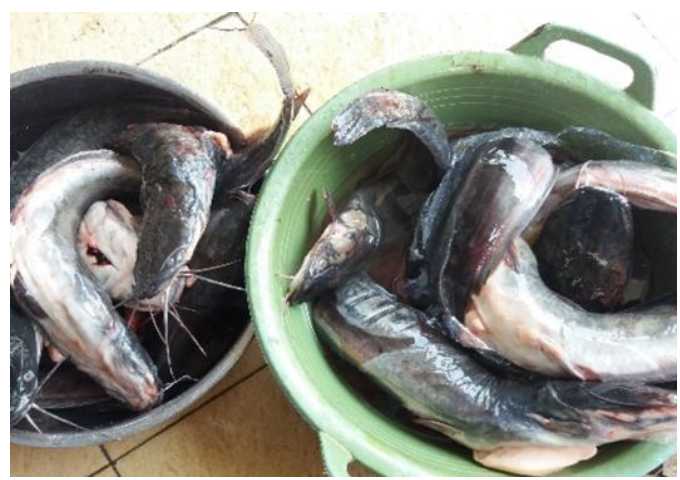

Gambar 2. Bahan baku

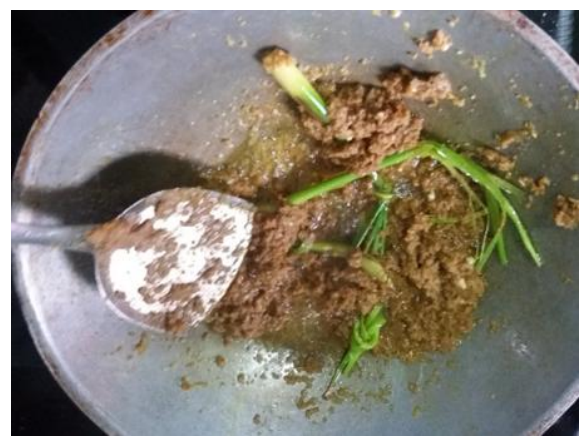

Gambar 4. Pemberian bumbu

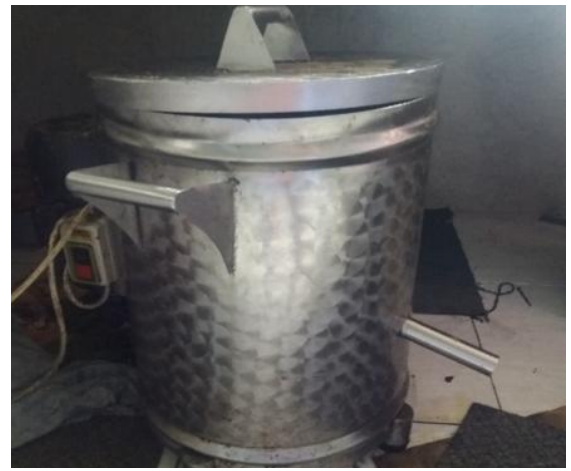

Gambar 6. Penirisan dan pengepresan

Abon lele yang sudah jadi dilakukan penimbangan, pengemasan dan labelling pastikan label telah memiliki tanggal kadaluarsa lalu tempelkan pada plastik alumunium. Pengemasan pada olahan abon lele memiliki berat 100

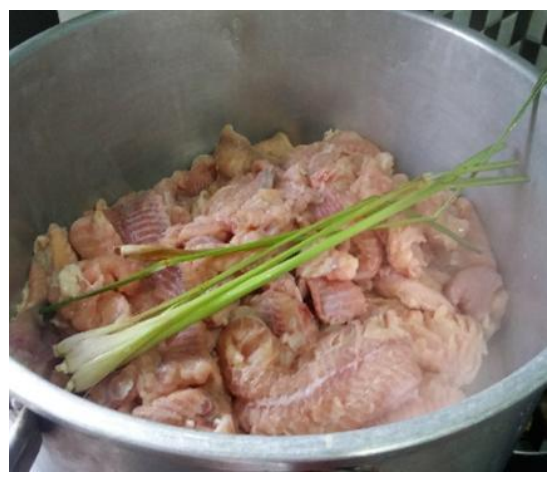

Gambar 3. Perebusan

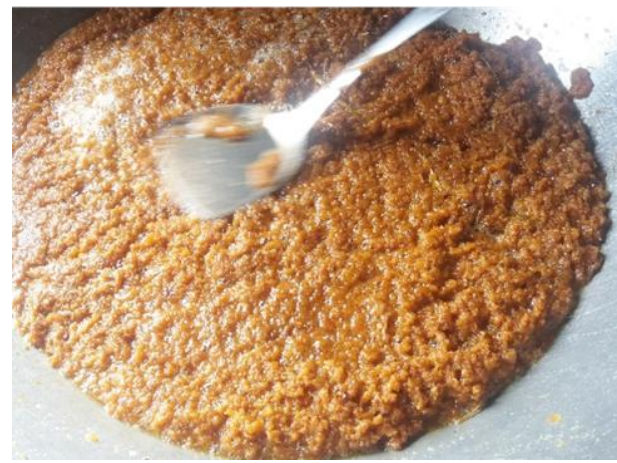

Gambar 5. Penggorengan

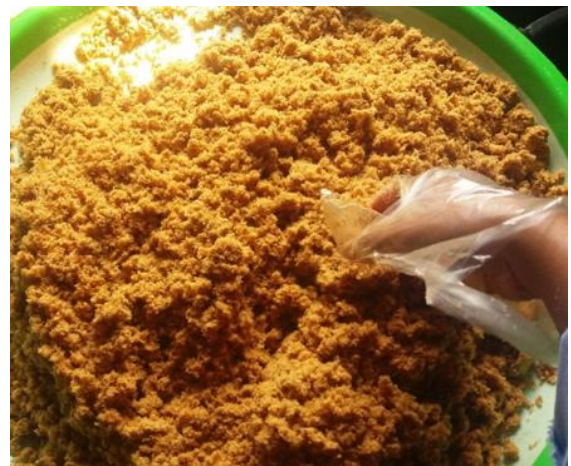

Gambar 7. Produk abon lele

gram, produk yang telah dikemas langsung disealer agar produk terjaga akan daya simpannya. Batas mengkonsumsi produk dapat disimpan maksimal selama 6 bulan. Gambar kemasan produk abon ikan lele dari 


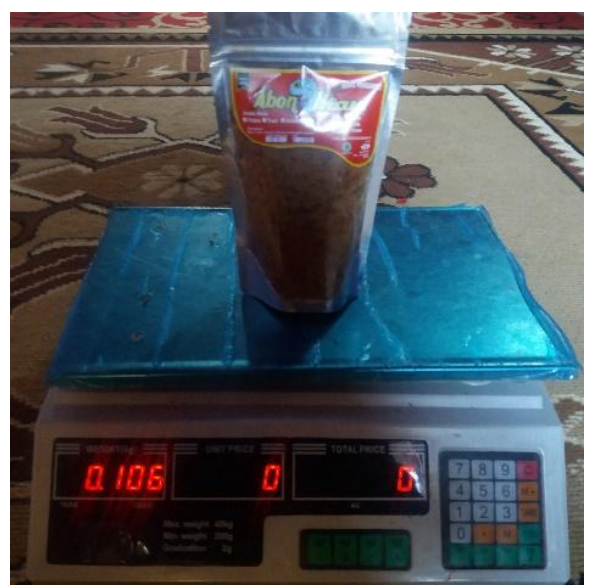

Gambar 8. Penimbangan dan pengemasan produk abon ikan lele

Tabel 1. Biaya tetap per bulan

\begin{tabular}{llr}
\hline No & \multicolumn{1}{c}{ Jenis Barang } & Nilai Beli (Rp) \\
\hline 1 & Biaya Listrik & $50.000,00$ \\
2 & Biaya Transportasi & $200.000,00$ \\
3 & Biaya Komunikasi & $70.000,00$ \\
4 & Biaya Penyusutan Investasi & $772.214,00$ \\
\hline & Jumlah biaya tetap & Rp.1.092.214,00 \\
\hline
\end{tabular}

P2MKP Jaya Mandiri disajikan pada Gambar 9.

Produk Produk abon ikan lele dari Kelompok P2MKP Jaya Mandiri telah bersertifikat halal dengan nomor 150200291112 pada tanggal 2 November 2012 dan sertifikasi PIRT dengan nomor 2023323120184-21.

Analisis kelayakan usaha abon lele Kelayakan usaha pengolahan abon ikan lele dianalisa menggunakan komponen-komponen analisa usaha. Jumlah biaya investasi yang diperoleh dari semua peralatan untuk 1 produk yang ada di P2MKP Jaya Mandiri jumlah biaya investasinya adalah $R p$ 98.948.000,00.

Jumlah biaya penyusutan yang diperoleh dari pengolahan abon ikan lele yang ada di P2MKP Jaya Mandiri yaitu dengan biaya penyusutannya adalah $\mathrm{Rp}$ $772.214,00$. Rincian biaya penyusutan disajikan pada Tabel 2. Perhitungan biaya penyusutan menggunakan rumus:

Penyusutan $=$ Harga Pembelian-Nilai Sisa /JUE 
Tabel 2. Biaya penyusutan investasi

\begin{tabular}{|c|c|c|c|c|c|}
\hline No & Jenis Barang & $\begin{array}{l}\text { Jumlah } \\
\text { (Buah) }\end{array}$ & Nilai Beli (Rp) & $\begin{array}{c}\text { JUE } \\
\text { (tahun) }\end{array}$ & $\begin{array}{c}\text { Biaya } \\
\text { Penyusutan } \\
\text { Perbulan (Rp) }\end{array}$ \\
\hline 1 & Etalase & 1 & $1.000 .000,00$ & 10 & $8.333,00$ \\
\hline 2 & Kompor & 2 & $1.000 .000,00$ & 3 & $27.777,00$ \\
\hline 3 & Selang Gas & 2 & $300.000,00$ & 4 & $6.250,00$ \\
\hline 4 & Mesin spinner & 1 & $3.500 .000,00$ & 8 & $36.458,00$ \\
\hline 5 & Tabung Gas & 1 & $120.000,00$ & 6 & $8.640,00$ \\
\hline 6 & $\begin{array}{l}\text { Alat pencetak } \\
\text { Exp. }\end{array}$ & 1 & $200.000,00$ & 3 & $5.555,00$ \\
\hline 7 & $\begin{array}{l}\text { Timbangan } \\
\text { Digital }\end{array}$ & 1 & $800.000,00$ & 8 & $8.333,00$ \\
\hline 8 & Celemek & 5 & $120.000,00$ & 5 & $2.000,00$ \\
\hline 9 & Sealer & 1 & $1.250 .000,00$ & 8 & $13.020,00$ \\
\hline 10 & Tampah & 4 & $116.000,00$ & 2 & $4.833,00$ \\
\hline 11 & Wajan besar & 2 & $560.000,00$ & 3 & $15.555,00$ \\
\hline 12 & Pisau & 10 & $120.000,00$ & 1 & $10.000,00$ \\
\hline 13 & Baskom & 5 & $250.000,00$ & 2 & $10.416,00$ \\
\hline 14 & Talenan & 5 & $125.000,00$ & 2 & $5.208,00$ \\
\hline 15 & Panci besar & 1 & $285.000,00$ & 3 & $7.916,00$ \\
\hline 16 & Serok & 2 & $100.000,00$ & 1 & $8.333,00$ \\
\hline 17 & Sutil & 5 & $160.000,00$ & 1 & $13.333,00$ \\
\hline 18 & Spatula plastik & 10 & $25.000,00$ & 1 & $2.083,00$ \\
\hline 19 & Cobek & 1 & $35.000,00$ & 1 & $2.916,00$ \\
\hline 20 & Toples & 2 & $432.000,00$ & 5 & $7.200,00$ \\
\hline 21 & Blender & 1 & $450.000,00$ & 3 & $12.500,00$ \\
\hline 22 & Bangunan & 1 & $80.000 .000,00$ & 12 & $555.555,00$ \\
\hline 23 & Motor & 2 & $8.000 .000,00$ & 5 & $133.333,00$ \\
\hline \multicolumn{5}{|c|}{ Jumlah biaya penyusutan } & $772.214,00$ \\
\hline
\end{tabular}

Total Biaya Produksi yang dikeluarkan dalam usaha abon ikan lele untuk satu bulan produksi adalah:

= Biaya Tetap + Biaya Variabel

$=\operatorname{Rp} 1.092 .214,00+\operatorname{Rp~430.200,00~}$

$=\operatorname{Rp} 1.522 .414,00$
Satu siklus produksi abon ikan lele menghasilkan 28 bungkus dan dalam 1 bulan dapat menghasilkan 336 bungkus. Dengan harga satuan yaitu $R p 17.000,00$ jadi pendapatan perbulan yang di peroleh yaitu $\mathrm{Rp} 5.712 .000,00$. 
Tabel 3. Biaya variabel produksi

\begin{tabular}{|c|c|c|c|c|c|}
\hline No & Nama Bahan & Jumlah & Satuan & $\begin{array}{c}\text { Harga } \\
\text { Satuan (Rp) }\end{array}$ & $\begin{array}{c}\text { Harga } \\
\text { Konsumsi } \\
(R p)\end{array}$ \\
\hline 1 & Ikan Lele & 10 & $\mathrm{Kg}$ & $20.000,00$ & $200.000,00$ \\
\hline 2 & Gula Pasir & 1 & $\mathrm{Kg}$ & $15.000,00$ & $15.000,00$ \\
\hline 3 & Plastik + merk & 28 & Buah & $1.300,00$ & $36.400,00$ \\
\hline 4 & Minyak Goreng & 5 & Liter & $13.000,00$ & $65.000,00$ \\
\hline 5 & Tenaga kerja & 3 & Orang & $20.000,00$ & $60.000,00$ \\
\hline 6 & Gas & 1 & Tabung & $20.000,00$ & $20.000,00$ \\
\hline 7 & $\begin{array}{l}\text { Ketumbar } \\
\text { bubuk }\end{array}$ & 1 & Sachet & $1.000,00$ & $1.000,00$ \\
\hline 8 & Lengkuas & 70 & $\mathrm{Gr}$ & $7.000,00$ & $7.000,00$ \\
\hline 9 & Jahe & 3 & Buah & 500,00 & 500,00 \\
\hline 10 & Bawang merah & 4 & Ons & $2.000,00$ & $8.000,00$ \\
\hline 11 & Bawang putih & 3 & Ons & $2.500,00$ & $7.500,00$ \\
\hline 12 & Serai & 6 & Batang & 300,00 & $1.800,00$ \\
\hline 13 & Garam & 150 & $\mathrm{Gr}$ & $2.000,00$ & $3.000,00$ \\
\hline 14 & Daun jeruk & 5 & Buah & $1.000,00$ & $5.000,00$ \\
\hline \multicolumn{5}{|c|}{ Total } & $430.200,00$ \\
\hline \multicolumn{5}{|c|}{ Harga Satu Bungkus } & $15.364,00$ \\
\hline \multicolumn{5}{|c|}{ Harga Jual } & $17.000,00$ \\
\hline \multicolumn{5}{|c|}{ Total Harga Jual } & $476.000,00$ \\
\hline \multicolumn{5}{|c|}{ Laba Satuan } & $1.636,00$ \\
\hline \multicolumn{5}{|c|}{ Laba Satu Kali Produksi } & $45.808,00$ \\
\hline
\end{tabular}

Perhitungan keuntungan dalam usaha abon ikan lele dalam 1 bulan produksi adalah sebagai berikut:

= Pendapatan - Total Biaya Produksi

$=\operatorname{Rp} 5.712 .000,00-\operatorname{Rp} 1.522 .414,00$

$=\operatorname{Rp~4.189.586,00.}$

Usaha pengolahan abon ikan lele ini mendapatkan nilai $R / C$ yaitu 3,7 artinya bahwa setiap penambahan biaya sebesar Rp 1000,00 maka akan di peroleh tambahan penerimaan sebesar Rp 3.700,00. Jika menurut perhitungan normal maka usaha ini layak untuk dilanjutkan.

Perhitungan payback periode diperoleh nilai 1,9. Investasi yang telah dikeluarkan pada usaha pengolahan abon ikan lele akan kembali jika 
memproduksi abon ikan lele tersebut selama 1 tahun 9 bulan.

Hasil perhitungan nilai BEP diperoleh nilai BEP sebesar Rp. 1.181.621,00. Usaha pengolahan abon lele akan mengalami titik impas apabila telah menghasilkan penjualan sebesar Rp 1.181.621,00 Apabila penjualan belum mencapai nilai tersebut maka usaha tersebut akan mengalami kerugian. Nilai BEP/unit adalah 667 artinya usaha pengolahan abon lele akan mengalami titik impas apabila telah memproduksi sebanyak 667 bungkus abon ikan lele.

Nilai ROI yang diperoleh pada produksi abon ikan lele tersebut adalah sebesar 3,7 \%, artinya dalam satu bulan produksi abon ikan lele mampu mengembalikan 3,7 \% dari biaya produksi yang telah di keluarkan.

\section{Pembahasan}

Manajemen usaha pengolahan abon lele

Usaha pengolahan abon lele pada Kelompok P2MK Jaya Mandiri belum sepenuhnya memiliki manajemen yang baik. Kelompok ini masih belum melakukan perencanaan usaha sepenuhnya. Usaha ini belum memiliki perencanaan baik untuk pembelian bahan baku, perluasan pemasaran maupun pelatihan untuk anggotanya. Namun kelompok telah memiliki organisasi yang baik, yang terdiri dari pengurus sejumlah tiga orang, yaitu Ketua, Sekretaris, Bendahara. Jumlah anggota telah bertambah menjadi 11 orang, yang merupakan penduduk setempat. Pada Kelompok 'Jaya Mandiri' anggota kelompok juga menjadi karyawan.

Perencanaan yang bisa dilakukan antara lain dengan mengembangkan fasilitas kolam ikan lele sendiri sehingga dapat menurunkan biaya pembelian bahan. Pengembangan fasilitas ini dapat dilakukan dengan perencanaan pengembangan modal usaha. Perencanaan pengembangan modal usaha dapat dilakukan dengan menggunakan pinjaman dari bank, dengan mempertimbangkan kemampuan pengembalian pinjaman yang rasional (Trihasa dkk. 2016).

Menurut Rahardi dkk. (2018) manajemen yang baik adalah manajemen usaha yang memiliki fungsifungsi manajemen yang terdapat dalam sebuah usaha perikanan, antara lain sebagai berikut:

\section{Perencanaan}

Fungsi ini merupakan tindakan untuk menentukan sasaran dan arah yang dipilih. Perencanaan dituntut kemampuan untuk meramalkan, mewujudkan, dan melihat kedepan dengan dilandasi oleh tujuan-tujuan tertentu. 
2. Pengorganisasian

Fungsi ini merupakan tindakan mengatur dan membagi-bagi bidang pekerjaan antara kelompok yang ada. Setelah terbentuk kelompok yang diperlukan, fungsi pengorganisasian akan menetapkan dan memperinci hubungan-hubungan yang diperlukan.

\section{Penggerakan}

Penggerakan merupakan gerakan untuk merangsang anggota-anggota kelompok agar melaksanakan tugastugas yang telah dibebankan dengan baik dan antusias.

\section{Pengawasan}

Fungsi ini merupakan tindakan untuk mengawasi aktivitas-aktivitas yang terkait agar dapat berjalan sesuai dengan rencana yang telah ditetapkan.

\section{Pengolahan abon ikan lele}

Bahan baku utama pada pembuatan abon adalah ikan lele segar yang diperoleh dari lokasi pasar dan budidaya setempat, sehingga kesegaran dan mutu abon ikan lele dapat terjaga. Kesegaran ikan merupa-kan salah satu komponen utama yang mempengaruhi mutu dari produk perikanan (Giannini dkk. 2001). Mutu produk ikan yang tinggi membuat biaya produksi menjadi lebih rendah. Biaya tenaga kerja menjadi rendah karena pekerjaan menangani ikan menjadi lebih sederhana, tidak banyak perlakukan tambahan yang dilakukan seperti pencucian berkali-kali, pembuangan atau penyiangan bahan yang tidak bermutu, serta penggunaan bahan-bahan tambahan lain, mengakibatkan waktu produksi menjadi lebih singkat (Chun dkk. 2014).

Bahan baku $10 \mathrm{~kg}$ daging ikan lele setelah diproses, menjadi $3 \mathrm{~kg}$ abon ikan, sehingga rendemen yang dihasilkan adalah 30\%. Rendemen abon ikan ini lebih rendah daripada rendemen abon ikan yang dibuat oleh CV. Duta Agro Lestari Kota Palu yang menghasilkan rendemen abon ikan sebesar 50\% (Batara dan Lamusa 2014).

Proses pembuatan abon ikan lele ini tidak menggunakan campuran bahan lain selain bumbu. Peningkatan rendemen dapat dilakukan dengan penambahan bahan lain seperti menggunakan kluwih (Artocarpus camasi), namun terjadi penurunan kadar protein abon, walaupun tingkat penerimaan konsumen masih tinggi hingga penambahan keluwih $60 \%$ (Rohmawati dkk. 2013). Penelitian lain menggunakan jantung pisang $25 \%$ dan $75 \%$ daging ikan tuna pada pembuatan abon ikan tuna (Dara dan Fanyalita 2017).

Penirisan produk abon ikan lele kemudian pengepresan berfungsi untuk mengurangi kadar minyak pada produk abon ikan lele. Kadar minyak yang tinggi 
dapat mempercerpat proses kemunduran mutu abon karena terbentuk senyawa turunan minyak seperti asam lemak bebas, hidrogen peroksida, asam tio barbiturik sebagai hasil oksidasi minyak oleh oksigen dan sinar matahari. Akibatnya abon ikan menjadi mudah berbau tengik (Dewi dkk. 2011). Penambahan vitamin $C$ sebagai antioksidan pada produk abon dapat mengurangi tingkat ketengikan abon (Aryani dan Evnaweri 2014).

Peralatan lain yang dapat digunakan untuk mengurangi kadar minyak adalah Alat Spinner Pulling Oil. Alat ini merupakan pengentas minyak otomatis elektrik yang memanfaatkan gaya sentrifugal dan menjadi solusi untuk mengatasi permasalahan pada skala industri rumah tangga hingga kadar lemak 25,49\% (Argo dkk. 2014).

Analisa dan Kelayakan usaha.

Hasil analisa dan kelayakan usaha dilihat dari perhitungan R/C yaitu 3,7 atau lebih dari 1, maka usaha pengolahan abon ikan lele layak untuk diusahakan. Nilai BEP tercapai jika produksi abon ikan lele mencapai 28 bungkus/siklus atau 336 bungkus/bulan atau 3360/tahun. Nilai BEP ini lebih tinggi dibandingkan dengan nilai BEP yang produksi abon ikan dari Kelompok Pengolahan Ikan Pantur di Kelurahan Humusu C Kecamatan Insana Utara
Kabupaten Timor Tengah Utara yaitu sebesar 435 unit/tahun (Kaet dan Hutapea 2016).

Harga satuan abon lele ini adalah Rp.17.000,00 per bungkus per $100 \mathrm{~g}$. Abon ikan lele ini lebih murah dibandingkan dengan abon ikan yang diproduksi oleh CV Duta Argo Lestari dengan kemasan 100-400 g mempunyai harga jual Rp. 20.000,00-Rp. 80.000,00. Produk abon ikan ini menggunakan kemasan yang berbeda tergantung pada target konsumen. Kemasan-kemasan yang digunakan antara lain mika, alumunium foil dan toples plastik (Batara dan Lamusa 2014).

\section{Pelabelan pada kemasan pangan}

Kemasan abon ikan lele ini telah memenuhi aturan dari BPOM Nomor HK.03.1.23.04.12.2205 tahun 2012 Tentang Pedoman Pemberian Sertifikat Produksi Pangan Industri Rumah Tangga dimana pada kemasan tersebut telah memuat informasi produk olahan seperti Nama jenis pangan (b) Nama dagang (c) Jenis kemasan (d) Berat bersih/isi bersih ( $\mathrm{mg} / \mathrm{g} / \mathrm{kg}$ atau $\mathrm{ml} / \mathrm{l} / \mathrm{kl})$ (e) Komposisi (f) Nama, alamat, kode pos IRTP (g) Informasi tentang masa simpan (kedaluwarsa) (k) Informasi tentang kode produksi. Namun informasi "bebas pengawet" atau tanpa bahan tambahan pangan pada kemasan tidak sesuai dengan Peraturan BPOM No 23 


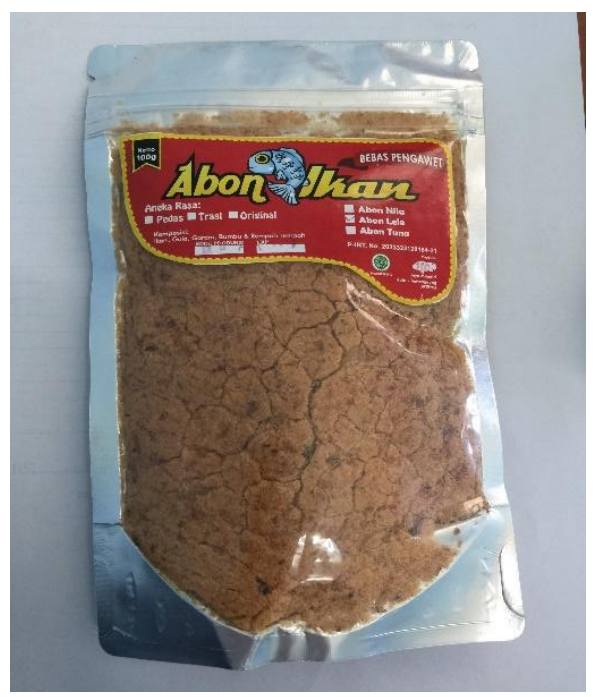

Gambar 9 Kemasan abon ikan lele

Tahun 2016 tentang Pencantuman Informasi Tanpa Bahan Tambahan Pangan pada Label dan Iklan Pangan. Pada peraturan tersebut, industri tidak boleh mencantumkan informasi atau iklan tanpa pemanis buatan, tanpa pengawet, tanpa pewarna sintetis, tanpa antioksidan, dan atau tanpa penguat rasa. Pelanggaran terhadap aturan tersebut akan mendapatkan peringatan, hingga pencabutan ijin edar.

\section{SIMPULAN DAN SARAN}

\section{Simpulan}

Berdasarkan penelitian yang dilaksanakan pada Kelompok P2MKP Jaya Mandiri, maka simpulan yang diambil adalah:

a. Dalam satu bulan usaha pengolahan abon ikan lele di P2MKP Jaya Mandiri memiliki pendapatan sebesar $\mathrm{Rp}$ 6.480.000,00 dan keuntungan sebesar Rp 1.463.942,00 dari olahan abon ikan lele. Dalam produk olahan abon ikan lele ini mendapatkan nilai R/C sebesar 1,29 artinya bahwa setiap pengeluaran biaya sebesar $R p$ $1.000,00$ maka akan di peroleh tambahan penerimaan sebesar $\mathrm{Rp}$ $1.290,00$.

b. Pengolahan abon ikan lele menghasilkan abon ikan yang bermutu karena berasal dari ikan lele segar. Rendemen abon yang dihasilkan adalah $30 \%$.

c. Manajemen usaha pengolahan Abon Ikan Lele di P2MKP Jaya Mandiri terlaksana dengan baik dimulai dari input produksi, proses produksi, pasca produksi hingga pemasaran yang dilaksanakan sebagaimana mestinya, walaupun mempunyai kelemahan belum melaksanakan perencanaan. Analisa kelayakan usaha secara perhitungan membuktikan bahwa P2MKP Jaya 
Mandiri adalah sebuah usaha pengolahan yang layak untuk dijalankan dan dapat menjadi sumber inovasi dan contoh dalam bidang usaha perikanan.

\section{Saran}

a. Meningkatkan produksi olahan abon ikan lele karena permintaan terus meningkat.

b. Menambah dan memperluas saluran pemasaran., seperti pemasaran melalui online shop akan banyak diketahui oleh orang dan sangat mudah untuk mempelajarinya.

c. Menambah jenis variasi olahan yang diproduksi, karena pada ikan lele sendiri hampir semua bisa diolah seperti: kulit, tulang, sirip itu bisa menjadi variasi olahan.

d. Perlu dilakukan upaya-upaya untuk meningkatkan pengetahuan karyawan tentang pentingnya pengawasan agar diperoleh produk yang baik dan dapat diterima oleh konsumen.

\section{PERSANTUNAN}

Ucapan terima kasih kepeda Kelompok P2MKP Jaya Mandiri yang telah mengijinkan dan memfasilitasi penulis melaksanakan penelitian ini.

\section{DAFTAR PUSTAKA}

Adebayo IA, Fapohunda OO, Ajibade AO. 2016. Evaluation of nutritional quality of clarias gariepinus from selected fish farms in Nigeria. Am. J. Food Sci. Nutr. Res. 3(4):56-62.

Argo BD, Lutfi M, Sugiarto Y. 2014. Rancang bangun alat "Spinner Pulling Oil" sebagai pengentas minyak otomatis dalam peningkatan mutu abon ikan patin (Pangaius pangaius) pada Koperasi Wanita Srikandi. Jurnal Teknologi Pertanian. 15(2):103110.

Aryani A, Evnaweri E. 2014. Kajian pemberian asam askorbat (vitamin C) dengan konsentrasi yang berbeda terhadap ketengikan abon ikan lele (Clarias batrachus). Fish Sci. 4(7):1-15.

Batara DL, Lamusa A. 2014. analisis titik pulang pokok usaha abon ikan pada CV. Duta Agro Lestari di Kota Palu. J. Agroteks 2(April):186-192.

Chun HN, Kim B, Shin HS. 2014. Evaluation of a freshness indicator for quality of fish products during storage. Food Sci. Biotechnol. 23(5):1719-1725.

Dara W, Fanyalita A. 2017. Pengaruh substitusi ikan tuna (Thunnus sp.) terhadap mutu organoleptik dan kimia abon jantung pisang (Musa acuminate balbisiana colla ). J. Sainstek 9(1):1-7. 
Dewi EN, Ibrahim R, Yuaniza N. 2011. Daya simpan abon ikan nila merah (Oreochromis niloticus trewavas) yang diproses dengan metoda penggorengan berbeda. J. Saintek Perikan. 6(1):6-12.

Direktorat Produksi Dan Usaha Budidaya. 2016. Peta Sentra Produksi Perikanan Budidaya.

Giannini D, Parin MA, Gadaleta L, Carrizo G, Zugarramurdi A. 2001. Influence of raw material quality on quality of iced and frozen white fish products. J. Food Qual. 24(6):527538.

Kaet L, Hutapea N. 2016. Analisis finansial usaha abon ikan pada Kelompok Pengolahan Ikan Pantura Di Kelurahan Humusu C Kecamatan Insana Utara Kabupaten Timor Tengah Utara. J. Agribisnis Lahan Kering 1(2502):82-83.

Kusumayanti $\mathrm{H}$, Astuti W, Broto RW. 2011. Inovasi pembuatan abon ikan sebagai salah satu teknologi pengawetan ikan 1). Gema Teknol. 16(3):119-121.

Ririsanti NN, Liviawaty E, Ihsan YN, Pratama RI. 2017. penambahan karagenan terhadap tingkat kesukaan pempek lele. J. Perikan. Dan Kelaut. 8(1):165-173.
Robinson EH, Li MH. 2015. A Brief Overview of Catfish Nutrition. MISSISSIPPI Agric. For. Exp. Stn. Res. Rep. 24(16):1-6.

Rohmawati N, Sulistiyani, Ratnawati LY. 2013. Pengaruh penambahan keluwih (Artocarpus camasi) terhadap mutu fisik, kadar protein, dan kadar air abon lele dumbo (Clarias gariepinus). J. IKESMA 9(2):127-135.

Trihasa R, Ikhwana A, Tinggi S, Garut T. 2016. Analisis rencana pengembangan usaha abon ikan lele. J. Kalibr. Sekoolah Tinggi Teknol. Garut 14(1):1-6.

Ubadillah A, Hersoelistyori W. 2010. Kadar protein dan sifat organoleptik nugget rajungan dengan substitusi ikan lele ( Clarias gariepinus) J. Pangan Dan Gizi . 01(02):45-54.

Rahardi, F. Kristinawati dan Nazarudin (2008). Agribisnis Perikanan. Penebar Swadaya. Jakarta.

Rustaman. (2015). Lele Ikan Favorit. Penerbit Putra Amanah Murni. Jakarta Timur.

Suryaningrum, T. D. (2012). Aneka Poduk Olahan Lele. Penebar Swadaya. Jakarta.

Suyitno H. 2014. Temanggung Budidayakan Ikan Nila, Lele, dan Mas. Senin, 23 Februari 2015, 
diakses pada https://jateng.

antaranews.com/detail/temang-

gung-budidayakan-ikan-nila-lele-

dan-mas.html. [diunduh tanggal 12

Juli 2018] 